\title{
NORMATIVIDADE DOS PRINCÍPIOS E O PRINCÍPIO DA DIGNIDADE DA PESSOA HUMANA NA CONSTITUIÇÃO DE 1988
}

\author{
ANa Paula de Barcellos* \\ 1. Introdução; 2. A norma jurídica - elementos essenciais; 3. Os prin- \\ cípios constitucionais e a normatividade; 4. Princípio da dignidade da \\ pessoa humana - conteúdo; 4.1. Da natureza da Constituição; 4.2. O \\ sistema constitucional em vigor; 5. Conclusão.
}

\section{Introdução}

Um dos poucos consensos teóricos do mundo contemporâneo diz respeito ao valor essencial do ser humano. Ainda que esse consenso restrinja-se muitas vezes apenas ao discurso ou que essa expressão, por demais genérica, seja capaz de agasalhar concepções as mais diversas - eventualmente contraditórias ${ }^{1}-$, o fato é que a dignidade da pessoa humana, o valor do homem como um fim em si mesmo, é hoje um axioma da civilização ocidental ${ }^{2}$, e talvez a única ideologia remanescente ${ }^{3}$.

1 Ignacio Ara Pinilla, Las transformaciones de los derechos humanos, Tecnos, Madrid, 1994, p. 32: " $Y$ es que, en efecto, desde puntos de vista teóricos muy diferentes se há venido insistinendo constantemente en que casi nunca se llegan a definir los derechos humanos, y, si se hace, no puede decirse que sea de manera satisfactoria, destacándose que 'se encierran en esas simples palabras significados distintos apoyados en fundamentos ideológicos y filosóficos también diferentes'."

2 Francisco Fernández Segado, La teoría jurídica de los derechos fundamentales en la Constitución Española de 1978 y en su interpretación por el Tribunal Constitucional, RILSF 121, p. 73: " En el ordenamiento liberal democrático la dignidad del hombre - según el Tribunal Constitucional Federal alemán - es el valor superior.".

3 Celso D. de Albuquerque Mello, Conflitos armados e direitos humanos, Renovar, Rio de Janeiro, 1997, p. 2 e Ignacio Ara Pinilla, Las transformaciones de los derechos humanos, Tecnos, Madrid, 1994, p. 91: "Vale la pena reseñar que, desde perspectivas teóricas que muy poco tienen que ver com la de este autor, se há destacado la función que cumplen los derechos humanos como sustituto de la que en outro tiempo pudo ocupar la religión."

* Advogada no Rio de Janeiro. Mestranda em Direito Público e Professora contratada da UERJ.

R. Dir. Adm.,

Rio de Janeiro, 221: 159-188,

jul./set. 2000 
É dispensável para o presente estudo percorrer com detalhes o caminho histórico - repleto de avanços e retrocessos - que alçou o homem, de joguete nas mãos dos deuses gregos ou de parte indistinta das comunidades nos Estados antigos, ao centro de seus próprios pensamentos e realizações, dentre os quais o Estado e o Direito. Será bastante assinalar quatro momentos fundamentais nesse percurso: o Cristianis$\mathrm{mo}^{4}$, o iluminismo-humanista, a obra de Immanuel $\mathrm{Kant}^{5}$ e o refluxo dos horrores da Segunda Guerra Mundial ${ }^{6}$, nessa ordem.

A mensagem divulgada por Jesus Cristo e seus sucessores representou um ponto de inflexão no mundo antigo. Pela primeira vez o homem passou a ser valorizado individualmente, já que a salvação anunciada não só era individual, como dependia de uma decisão pessoal. A conseqüência que se extrairia naturalmente dessa circunstância, mas que foi expressamente verbalizada pelo apóstolo São Paulo e pelos Pais da Igreja, diz respeito à igualdade essencial dos homens. A conhecida declaração "Nisto não há judeu nem grego; não há servo nem livre; não há macho nem fêmea; porque todos vós sois um em Cristo Jesus." ", teve um compreensível efeito subversivo no mundo romano.

Muitos séculos depois, o movimento iluminista, com sua crença fervorosa na razão humana, foi o responsável por desalojar a religiosidade do centro do sistema de pensamento, substituindo-a pelo próprio homem. O desenvolvimento teórico do humanismo acabará por redundar em um conjunto de conseqüências relevantes para o desenvolvimento da idéia de dignidade humana, como a preocupação com os direitos individuais do homem e o exercício democrático do poder. Com efeito, a regra majoritária era a fórmula capaz de realizar a igualdade essencial de cada homem no âmbito da deliberação política ${ }^{8}$.

Em terceiro lugar, e seguindo o curso histórico, não se pode deixar de mencionar o pensamento de Immanuel Kant. É Kant quem vai apresentar a formulação mais consistente - e evidentemente complexa - da natureza humana e de suas relações consigo próprio, com o próximo e com as criações do próprio homem e da natureza.

4 Miguel Reale, Questōes de direito público, Saraiva, São Paulo, 1997, p. 3 e ss..

5 Norberto Bobbio, Direito e estado no pensamento de Emanuel Kant, 4* ed., Trad. Alfredo Fait, UNB, Brasíia, 1997, p. 31 e ss., Norberto Bobbio, Estado, Governo, Sociedade, 7 ed., Trad. Marco Aurélio Nogueira, Paz e Terra, SP, 1999, p. 108 e ss. e Pierre Hassner, Immanuel Kant in History of politcal philosophy, ed. Leo Strauss and Joseph Cropsey, $3^{2}$ ed., The University of Chicago Press, Chicago, 1987, p. 581.

6 Franciso Fernández Segado, La teoria jurídica de los derechos fundamentales en la Constitución Española de 1978 y en su interpretación por el Tribunal Constitucional, RILSF 121, p. 76 e Ricardo Lobo Torres, Os direitos humanos e a tributaçäo - Imunidades e isonomia, Renovar, Rio de Janeiro, 1995 , p. 45 e ss.

7 A referência consta da carta escrita pelo apóstolo Paulo aos Gálatas, capítulo 3, verso 28.

8 J. J. Gomes Canotilho, Direito constitucional e teoria da constituiçāo, Almedina, Coimbra, 1997, p. 311: "As raizes do principio maioritário reconduzem-se aos principios da igualdade democrática, da liberdade e da autodeterminação. Se a liberdade de participação democrática é igual e vale para todos os cidadãos, entäo o estabelecimento vinculativo de uma determinada ordenação jurídica pressupōe, pelo menos, a concordância da maioria." 
No que mais diretamente nos interessa, e de uma forma bastante simplificada, pode-se dizer que, para Kant, o homem é um fim em si mesmo - e não uma função do Estado, da Sociedade ou da nação - dispondo de uma dignidade ontológica. $\mathrm{O}$ Direito e o Estado, ao contrário, é que deverão estar organizados em benefício dos indivíduos. Assim é que Kant sustenta a necessidade da separação dos poderes e da generalização do princípio da legalidade como forma de assegurar aos homens a liberdade de perseguirem seus projetos individuais ${ }^{9}$.

Interessantemente, e nada obstante os vários retrocessos históricos, a concepção kantiana de homem continua a valer como axioma no mundo ocidental, ainda que a ela tenham se agregado novas preocupações, como a tutela coletiva dos interesses individuais e a verificação da existência das condições materiais indispensáveis para o exercício da liberdade ${ }^{10}$.

$\mathrm{Na}$ verdade, nas primeiras décadas do século $\mathrm{XX}$ a concepção humanista já havia se transformado no conhecimento comum do chamado "mundo civilizado", tanto assim que as Constituições já há algumas décadas procuravam consagrar os direitos individuais e alguma forma de separação de poderes. A partir do fim da Primeira Guerra Mundial, a preocupação com os chamados direitos sociais será progressivamente introduzida nos textos constitucionais ${ }^{11}$.

O último momento especialmente marcante no percurso histórico da noção de dignidade da pessoa humana, é também o mais chocante. A revelação dos horrores da Segunda Guerra Mundial transtornou completamente as conviç̧ões que até ali se tinham como pacíficas e "universais" 12 . A terrível facilidade com que milhares de pessoas - não apenas alemãs, diga-se, mas de diversas nacionalidades européias - abraçaram a idéia de que o extermínio puro e simples de seres humanos podia consistir em uma política válida de governo ainda choca.

Agrega-se a isso a assustadora verificação de Hannah $\operatorname{Arendt}^{13}$ de que, na Segunda Guerra, as próprias vítimas (a autora se refere especificamente aos judeus) perderam em boa medida a compreensão do valor inerente à vida humana, daí a

9 Antonio Enrique Pérez Luño, Derechos humanos, estado de derecho y constitucion, 6" ed., Tecnos, Buenos Aires, 1999, p. 215: "Kant acepta, en principio, la tesis del iusnaturalismo iluminista de que el Estado es un medio y una condición para asegurar las respectivas esferas de libertad de los ciudadanos, por medio del derecho." .

10 Caio Tácito, Do Estado Liberal ao Estado do Bem-Estar Social, in Temas de Direito Público, Renovar, RJ, 1997, p. 381: "É importante assinalar que, no Estado Liberal clássico como no moderno Estado do Bem-Estar Social (Welfare State), o destinatário último é o indivíduo. Os direitos sociais, na ordem democrática, têm por endereço o aperfeiçoamento das liberdades e direitos individuais, como garantia do homem contra os riscos sociais. A ą̧āo do Estado, dando eficácia àqueles, não pode ser entendida ou exercida no sentido de anular estes, senão de completá-los, somando, num feixe comum, a suprema proteção do homem nas várias relaçōes jurídicas de que participe: como proprietário, cidadão, empresário ou trabalhador." (grifos no original).

11 Norberto Bobbio, A era dos direitos, Trad. Carlos Nelson Coutinho, Campus, São Paulo, 1992. 12 É bem de notar que o "universalidade" diz respeito apenas ao mundo ocidental.

13 Hannah Arendt, Eichmann em Jerusalém - Um relato sobre a banalidade do mal, Trad. José Rubens Siqueira, Companhia das Letras, São Paulo, 1999. 
prática comum pela qual os próprios líderes das comunidades judaicas negociavam a libertação de judeus mais importantes ou cultos, em troca de judeus "comuns", como se aqueles valessem mais que estes.

A reação à barbárie do nazismo e dos fascismos em geral levou, no pós-guerra, à consagração da dignidade da pessoa humana no plano internacional ${ }^{14} \mathrm{e}$ interno como valor máximo dos ordenamentos jurídicos e princípio orientador da atuação estatal e dos organismos internacionais. Mais importante que isso, talvez, foi, e é, a preocupação com a realização efetiva e generalizada dessa dignidade essencial.

Com efeito, diversos países cuidaram de introduzir em suas Constituições a dignidade da pessoa humana como fundamento do Estado que se criava ou recriava (Alemanha, Portugal e Espanha, v.g., em suas novas Cartas; a Bélgica tratou do tema através de emenda à constituição ${ }^{15}$ ). Também a Constituição Brasileira de 1988 introduziu o princípio, pela primeira vez, em seu artigo $1^{\circ}$, III.

A esse movimento de constitucionalização do princípio da dignidade da pessoa humana veio se associar o esforço mais geral engendrado pela doutrina de assegurar a realização prática das Constituições como um todo. Com efeito, mais um subproduto do pós-Guerra foi a percep̧̧ão do fracasso da Constituição de Weimar e da

14 Norberto Bobbio, Nicola Matteucci e Gianfranco Pasquino, Dicionário de Política, 12ª ed., Trad. Carmen C. Varriale e outros, UNB, Brasilia, 1999, p. 355 e ss..

15 Sobre a Constituição portuguesa: J. J. Gomes Canotilho, Direito constitucional e teoria da constituiçāo, Almedina, Coimbra, 1997, p. 219: "Outra esfera constitutiva da República Portuguesa é a 'dignidade da pessoa humana' (artigo $2^{\circ}$ ). (...) Perante as experiências históricas da aniquilaçâo do ser humano (inquisição, escravatura, nazismo, stalinismo, polpotismo, genocídios étnicos) a dignidade da pessoa humana como base da República significa, sem transcendências ou metafisicas, o reconhecimento do homo noumenon, ou seja, do individuo como limite e fundamento do domínio político da República. Neste sentido, a República é uma organização politica que serve $o$ homem, não é o homem que serve os aparelhos político-organizatórios."

Sobre a Constituição Espanhola: Franciso Fernández Segado, La teoría juridica de los derechos fundamentales en la Constitución Española de 1978 y en su interpretación por el Tribunal Constitucional, RILSF 121, p. 73: "El art. 10..1 de la Constitución - al que nos referimos com anterioriedad - supone la consagración de la persona y de su dignidad no sólo como el fundamento de la totalidad del orden político, sino, y por ello mismo, tambie'n como el principio rector supremo del ordenamimento jurídico."

Sobre a Constituição alemã: Konrad Hesse, Elementos de direito constitucional da República Federal da Alemanha, Trad. Luís Afonso Heck, Sergio Antonio Fabris Editor, Porto Alegre, 1998, p. 109/1 10: "(...) o artigo de entrada da Lei Fundamental normaliza o princípio superior, incondicional e, na maneira da sua realização indisponivel, da ordem constitucional: a inviolabilidade da dignidade do homem e a obrigação de todo o poderes estatal de respeitá-la e protegê-la."

Sobre a reforma da Constituiçāo belga: Francis Delpérée, $O$ direito à dignidade humana in Direito constitucional - Estudos em homenagem a Manoel Gonçalves Ferreira Filho, Coord. Sérgio Resende de Barros e Fernando Aurelio Zilveti, Dialética, 1999, p. 151: “(...) Nunca é demais repetir. A Constituição belga é uma antiga Constituição. É uma Constituição 'dos tempos de Luiz Felipe' (...) foi revisada, em 31 de janeiro de 1994, (...): 'Cada um - e está indicado, nos primeiros comentários, que a expressão não designaria unicamente os belgas, mas tende a englobar todos aqueles que se encontram a um título ou a outro dentro do território belga - tem o direito de levar uma vida de acordo com a dignidade humana'." 
própria concepção, até então vigente, das normas constitucionais como meros programas indicativos para o legislador.

Em oposição a essa experiência, a segunda metade do século $\mathrm{XX}$ vai conhecer o desenvolvimento de um novo discurso a respeito da Constituição: o discurso normativo. As normas constitucionais, a partir de agora, serão consideradas como normas jurídicas e, como tais, dirigidas a toda a sociedade, em especial ao Poder Judiciário e aos indivíduos.

$\mathrm{Na}$ concepção atual, portanto ${ }^{16}$, as normas constitucionais são normas jurídicas, isto é: são imperativas, existem para realizar-se e estão à disposição de todos os jurisdicionados. Este é o pressuposto lógico deste estudo e adiante se voltará ao tema mais detalhadamente.

É no encontro dessas duas idéias, hoje consagradas - a dignidade da pessoa humana, valor fundamental do Estado que aspira realização, e a normatividade da Constituição que, igualmente, busca realizar-se - que se vislumbram uma série de perplexidades.

Ora: que significa que a dignidade da pessoa humana é um principio fundamental da República, como dispõe a Constituição Brasileira? Trata-se de uma norma-regra, uma norma-princípio ou de alguma coisa diversa? Que efeitos práticos tal disposição é capaz de produzir? Que se pode exigir com fundamento nela? Qual o conteúdo afinal da dignidade da pessoa humana? Que diz a Constituição Brasileira de 1988 sobre o assunto? Estas são algumas das questões que se pretende tocar no presente estudo, ainda que, evidentemente, sem pretensōes de exaustividade e com a atenção voltada para a realidade jurídica brasileira

O caminho que se procurará trilhar passa, em primeiro lugar, por uma noção geral da norma jurídica e de suas características essenciais para, em seguida, aplicar esses dados às normas constitucionais, tanto às regras como, especialmente, aos princípios, partindo do esquema, hoje já consagrado, que classifica as regras e os princípios como espécies do gênero norma ${ }^{17}$.

Em uma segunda parte, pretende-se identificar as dificuldades lógicas que impedem a plena normatividade dos princípios - especialmente do princípio da dignidade da pessoa humana - para, por fim, examinar as potencialidades do texto

16 Refere-se, por todos, Konrad Hesse, A força normativa da Constituiçāo, Trad. Gilmar Ferreira Mendes, Sergio Antonio Fabris Editor, Porto Alegre, 1991; o trabalho, texto base da aula inaugural do autor na Universidade de Freiburg, em 1959, se tornou um documento fundamental para o moderno constitucionalismo normativo. Veja-se também, Eduardo Garcia de Enterria, La Constitucion como norma y el Tribunal Constitucional, 3* ed., Editorial Civitas, Madrid, 1985, p. 64 e ss.. Na produção nacional merecem destaque, dentre outros, o trabalho pioneiro de José Afonso da Silva, Aplicabilidade das normas constitucionais, $3^{2}$ ed., Malheiros, São Paulo, 1998 (a primeira edição é de 1967) e Luís Roberto Barroso, $O$ direito constitucional e a efetividade de suas normas, $3^{2}$ ed., Renovar, Rio de Janeiro, 1998.

17 Veja-se, por todos, Robert Alexy, Teoria de los derechos fundamentales, Trad. Ernesto Garzón Valdés, Centro de Estudios Constitucionales, Madrid, 1997, p. 83 e Norberto Bobbio, Teoria do ordenamento jurídico, Trad. Maria Celeste Cordeiro Leite dos Santos, $10^{*}$ ed., Editora UNB, Brasília, 1997, p. 158/9. 
de 1988 na maximização da normatividade do princípio da dignidade da pessoa humana e de seu conteúdo.

\section{A norma jurídica - elementos essenciais}

A concepção normativa da Constituição quer significar que todas as normas constitucionais são normas jurídicas. Nada obstante, quando se afirma que a Constituição é norma jurídica ou, mais que isso, que os princípios nela inscritos são espécies de normas ${ }^{18}$, é preciso esclarecer com a precisão possível os conceitos utilizados. Isto é: que significa ser uma norma jurídica? Ou melhor: qual a nota essencial da norma jurídica que se atribui às normas constitucionais em geral para que se possa legitimamente designá-las como jurídicas?

Antes mesmo de mergulhar na classificação das normas (seja com fundamento em sua estrutura lógico-lingüística ou em sua função no ordenamento), a moderna teoria da norma identifica como elemento essencial do direito em geral, e da norma jurídica em particular, a imperatividade dos efeitos propostos. Isto é: a capacidade de impor pela força, se necessário, a realização dos efeitos pretendidos pela norma ${ }^{19}$ ou de associar algum tipo de consequiência ao descumprimento voluntário da norma, consequiência essa capaz de impor, ainda que substitutivamente, a realização do efeito normativo inicialmente previsto ou um seu equivalente ${ }^{20}$. É o que Karl Larenz ${ }^{21}$ qualifica como ordenação de vigência, característica típica de cada proposição jurídica.

É importante ressaltar, no entanto, como faz Norberto Bobbio, que uma norma não existe sozinha, isoladamente, mas sempre estará inserida no conjunto do ordenamento. De fato, tanto a precisa identificação do efeito pretendido pela norma (ou

18 Paulo Bonavides, Curso de direito constitucional, $8^{2}$ ed., Malheiros, São Paulo, 1999, p. 228 e ss. faz uma preciosa exposição sobre a evoluçāo histórica da normatividade dos princípios constitucionais.

19 Karl Engish, Introdução ao pensamento jurídico, Trad. J. Baptista Machado, 6" ed., Fundação Calouste Gulbenkian, Lisboa, 1983, p. 27 e ss., Norberto Bobbio, Teoria do ordenamento jurídico, Trad. Maria Celeste Cordeiro Leite dos Santos, 10 ed., Editora UNB, Brasília, 1997, p. 21 e 22 , Giorgio Del Vecchio, Lições de filosofia do direito, Trad. António José Brandão, Arménio Amado Editor, Coimbra, 1979, p. $339 / 340$ e San Tiago Dantas, Programa de Direito Civil, Parte Geral, Editora Rio, Rio de Janeiro, 1977, p. 57 e ss..

20 Em algumas situações simplesmente não é possivel que o efeito originalmente pretendido pela norma se realize, ainda com a intervenção da força. Os casos mais clássicos dessa limitação do ordenamento se referem ao descumprimento de obrigaçōes personalíssimas, que só poderāo ser substituídas pela reparação pecuniária. Situação totalmente peculiar é a do direito penal que, na maior parte dos casos, exceto nos crimes contra o patrimônio, não tem condições de oferecer uma forma coativa substitutiva dos efeitos da norma que não tenham sido observados. A sanção no direito penal tem natureza e funçāo diversas, cujo estudo está fora dos objetivos deste trabalho.

21 Karl Larenz, Metodologia da ciência do direito, Fundaçāo Calouste Gulbenkian, Lisboa, 1968, p. 214. 
conjunto de normas), como o meio de garanti-lo coativamente mobilizam o ordenamento jurídico como um todo. Assim se expressa Norberto Bobbio sobre o ponto:

“(...) se pode falar de Direito somente onde haja um complexo de normas formando um ordenamento, e que, portanto, o Direito não é norma, mas um conjunto coordenado de normas, sendo evidente que uma norma jurídica não se encontra jamais só, mas está ligada a outras normas com as quais forma um sistema normativo. (...) a consideração do modo pelo qual uma determinada norma se torna eficaz a partir de uma complexa organização que determina a natureza e a entidade das sanções, as pessoas que podem exercê-las e a sua execução. Essa organização complexa é o produto de um ordenamento jurídi$\mathrm{co}^{22}$

Exemplificando, a norma que qualifica como abusivas as multas moratórias superiores a $2 \%$ nos contratos de financiamento (Lei $n^{\circ} 8.078 / 90$ ) garante ao mutuário, v.g., a redução forçada da multa eventualmente fixada em níveis superiores ao permitido em lei pelo Poder Judiciário. A ordenação de vigência, v.g., confere à norma que prevê a maioridade civil, para determinados fins, aos 18 anos, a capacidade de obrigar todos - juízes, administradores e particulares - a aceitar os efeitos por ela dispostos (em conjunto com outras normas do ordenamento) como, v.g., o que prevê a inimputabilidade do menor de $18 \operatorname{anos}^{23}$, impedindo o juiz de condenar um menor criminalmente.

O mesmo acontece, e agora tomando-se como exemplo uma categoria diversa de norma, com o princípio que veda o enriquecimento sem causa. Nas hipóteses a que se aplica a chamada teoria da imprevisão - nas quais um fato superveniente imprevisível altera substancialmente a comutatividade da relação contratual em favor de uma das partes - não causa maior espécie que a imperatividade do princípio obrigue a parte beneficiada a se conformar com a reorganização da relação jurídica levada a cabo pelo Poder Judiciário, de modo a impedir o enriquecimento sem causa de uma das partes em detrimento exclusivo da outra.

Não é diferente o que se passa com o princípio da boa fé no âmbito da atuação do Poder Público - e chega-se assim a um exemplo de direito público. É corriqueiro o entendimento de que o direito dos particulares que se fiaram em atos posteriormente revogados pela Administração, por conveniência e oportunidade, deverão ser preservados ensejando até mesmo, se for o caso, a obrigação de indenizar por parte da Administração Pública ${ }^{24}$.

É importante observar, em cada um dos quatro exemplos referidos, o efeito pretendido pela norma (regra ou princípio) e a imperatividade a ele concedida pelo

22 Norberto Bobbio, Teoria do ordenamento jurídico, Trad. Maria Celeste Cordeiro Leite dos Santos, 10 ed., Editora UNB, Brasília, 1997, p. 21 e 22.

23 No caso, inclusive, uma norma constitucional: Constituição Federal, art. 228.

24 Especificamente sobre o tema, confira-se, por todos, Celso Antônio Bandeira de Mello, Curso de direito administrativo, $11^{2}$ ed., Malheiros, São Paulo, 1999, p. 328 e ss.. 
Direito, isto é, a capacidade de impor a realização desse efeito de forma coativa. No primeiro caso, o efeito pretendido pela norma é simples e está inteiramente contido em um mesmo comando: a multa moratória não pode ser superior a $2 \%$. $O$ Judiciário poderá obrigar qualquer renitente a cumprir tal disposição. No segundo exemplo o da maioridade - o ordenamento agrega a essa norma um conjunto de efeitos que, caso descumpridos, poderão igualmente ser assegurados coativamente pelo Poder Judiciário. Assim, v.g., o processo penal no qual se venha a condenar menor, poderá ser anulado ou as núpcias contraídas por menores, sem autorização, poderão igualmente ser anuladas.

No terceiro caso, cuida-se de uma norma-princípio cujo objetivo é que ninguém venha a enriquecer sem uma justa causa. Embora, o efeito pretendido por esta norma seja capaz de abranger um conjunto heterogêneo de situações, diferentemente dos casos acima referidos, também aqui o meio de assegurar que o pretendido pela norma seja cumprido foi obrigar o favorecido - por meio da intervenção do Judiciário a abrir mão daqueles benefícios injustificados, de forma a retomar o equilibrio da relação jurídica. Ou, por outro lado, conceder ao prejudiciado o direito de exigir judicialmente o reequilibrio do ajuste.

Por fim, no último exemplo, o que a norma-princípio pretende é que a Administração Pública se conduza com boa fé, de modo que os administrados não sejam surpreendidos e possam agir confiados nas ações do Poder Público. A solução para garantir esse efeito final, construída pela doutrina e jurisprudência, é assegurar que os particulares que se envolveram em relações jurídicas confiados na ação da Administração não sofram prejuízos, nem tenham sua situação alterada, ainda que o Poder Público efetivamente venha a revogar o ato que deu ensejo à formação de tais relações.

Tendo em mente esse elemento inicial e absolutamente essencial à ordem jurídica - a imperatividade dos efeitos previstos pelas normas - é possível fazer três observações.

Em primeiro lugar, é preciso identificar qual o efeito que cada norma pretende produzir no mundo dos fatos, o que poderá ser apurado pelo exame da proposição jurídica isoladamente, de um subsistema do ordenamento ou até mesmo do ordenamento como um todo. A identificação do efeito pretendido pela norma é, provavelmente, o momento mais importante na construção de sua imperatividade ${ }^{25}$.

Em segundo lugar, deverá se apurar também, diante da eventual não realização espontânea do resultado pretendido pela norma, qual a consequiência jurídica que o dispositivo especificamente, ou o ordenamento em geral, associa ao caso de modo a garantir-lhe o cumprimento. Este é o momento em que vai se verificar o que é possível fazer, em cada caso, para assegurar o cumprimento da norma desrespeitada.

Em três dos exemplos dados, a norma permitia a redução da multa, a revisão do contrato atingido pela teoria da imprevisão e a indenização pelos danos causados

25 Karl Engish, Introdução ao pensamento jurídico, Trad. J. Baptista Machado, $6^{*}$ ed., Fundação Calouste Gulbenkian, 1983, p. 27. O autor afirma que a importância da descrição da hipótese legal está precisamente na atribuição de efeitos jurídicos que a norma liga às situaçōes descritas. 
pela Administração Pública. Note-se que, como regra geral, a conseqüência jurídica associada à norma utiliza a fórmula de criar um direito subjetivo para aquele que seria beneficiado ou simplesmente atingido pela realização dos efeitos da norma e não o foi ${ }^{26}$, de modo que ele possa exigir judicialmente que os referidos efeitos se produzam. Poder-se-ia chamar essa conseqüência de perfeitamente simétrica.

Nada obstante, embora esta seja a regra, nem sempre o ordenamento jurídico atribui uma conseqüência jurídica perfeitamente simétrica ao efeito normativo pretendido, como nos casos acima referidos. Com efeito, caso alguém pretenda cobrar uma multa moratória superior a $2 \%$, bastará à parte pedir ao Judiciário que obrigue o cobrador a contentar-se com os $2 \%$ legais. Em outros casos, todavia, o ordenamento cria consequiências jurídicas específicas, como a possibilidade de apenas algumas pessoas, em determinado prazo, anularem o casamento do menor não autorizado (Código Civil, arts. 183, XI, 209 e 212). Ou ainda agrega à consequiência jurídica simétrica outras consequiências de natureza totalmente diversa, como, v.g., a possibilidade de responsabilização da autoridade que não oferece ou oferece irregularmente ensino fundamental gratuito (CF, art. 208, $\S 2^{\circ}$ ).

Em terceiro lugar, em qualquer situação será preciso um meio de tutela judicial através do qual a conseqüência jurídica possa ser implementada e os efeitos inicialmente pretendidos pela norma assegurados. Este ponto não será objeto específico de nosso estudo e por isso demanda breve nota desde logo.

A outorga de uma ampla tutela jurídica é um princípio fundamental do Estado de Direito ${ }^{27}$, sem a qual as normas jurídicas limitam-se a palavras no papel, meros conselhos ou normas morais. Este é um ponto fundamental. Não basta reconhecer a relevância de um comportamento ou de uma determinada situação; é preciso que haja um meio próprio e eficaz de vindicá-los em Juízo.

Assim, e esta é a conclusão do Professor José Carlos Barbosa Moreira ao examinar o tema, o processo deve dispor de instrumentos de tutela adequados a todos os direitos ou outras posições jurídicas de vantagem contempladas no ordenamento, quer resultem de expressa previsão normativa, quer se possam inferir do sistema . Cabe à doutrina, na recomendação do ilustre Professor, trabalhar para desenvolver o tema de modo a criar as categorias acionáveis necessárias para instrumentalização das previsōes normativas ${ }^{28}$. Como registrado pelo Professor Barbosa Moreira, este ainda é um ponto a construir, especialmente no que diz respeito ao direito público e, de forma ainda mais acentuada, ao direito constitucional.

26 Luís Roberto Barroso, $O$ direito constitucional e a efetividade de suas normas, $3^{2}$ ed., Renovar, Rio de Janeiro, 1998, p. 97 e ss.: “(...) direito subjetivo (...) um vínculo, uma relação juridica que estabelece um elo entre dois componentes: de um lado, o direito subjetivo, a possibilidade de exigir; de outro, o dever jurídico, a obrigação de cumprir.".

27 Karl Larenz, Derecho justo - Fundamentos de etica juridica, Trad. Luis Díez-Picazo, Editorial Civitas, S.A., Madrid, 1991, p. 176 e ss. e Mauro Cappelletti, Proceso, Ideologias, Sociedad, Trad. Santiago Sentís Melendo y Tomás A. Banzhaf, Ediciones Juridicas Europa-America, Buenos Aires, 1974 , p. $369,520$.

28 José Carlos Barbosa Moreira, Notas sobre o problema da "efetividade" do processo in Temas de Direito Processual, Terceira Série, Saraiva, São Paulo, Saraiva, 1984, p. $27 / 33$. 
Com efeito, e em conclusão deste ponto, é preciso lembrar que as normas constitucionais, embora normas jurídicas, apresentam peculiaridades que as diferenciam dentro do sistema ${ }^{29}$. Exatamente porque não se pode ignorar tais peculiaridades é que será necessário aplicar com um cuidado teórico específico, e com as adaptações necessárias, o roteiro acima descrito (efeito jurídico, consequiência jurídica e tutela) também às normas constitucionais.

$O$ fato de existirem dificuldades nessa transposição, entretanto, não justifica de forma alguma a postura dogmática de abandono da Constituição à sua própria sorte, descuidando-se de assegurar a seus preceitos as conseqüências próprias das normas jurídicas. Além disso, é tecnicamente condenável a postura teórica de que a locução 'norma jurídica' significa algo diverso quando se trata de norma constitucional ou não significa coisa alguma. Como registrou o Professor Clèmerson Merlin Clève: "Mais do que isso, importa, hoje, para o jurista participante, sujar as mãos com a lama impregnante da prática jurídica, oferecendo, no campo da dogmática, novas soluções, novas fórmulas, novas interpretações, novas construções conceituais. Este é o grande desafio contemporâneo." ${ }^{30}$

Se as normas constitucionais são normas jurídicas - e o são: este é um axioma a respeito do qual não se transige - compartilham elas ao menos do elemento mais essencial da normatividade: também elas pretendem produzir efeitos que deverão ser levados a cabo coativamente se necessário.

A grande questão é precisamente procurar identificar o efeito pretendido pelas normas constitucionais e a consequiência jurídica a ele associada para, em seguida, fazer uso de algum meio de tutela capaz de impor seu cumprimento. As particularidades das normas constitucionais evidentemente surgirão e serão abordadas ao longo do caminho. $\mathrm{O}$ objetivo do próximo ponto é aplicar as idéias expostas acima aos princípios constitucionais e, particularmente, ao princípio da dignidade da pessoa humana.

\section{Os princípios constitucionais e a normatividade}

De acordo com o ensinamento corrente da moderna doutrina constitucional, os princípios são, ao lado das regras, espécie de normas, dotados de imperatividade. Ruy Samuel Espíndola em seu Conceito de princípios constitucionais ${ }^{31}$ faz um valioso levantamento da doutrina nacional sobre o ponto pelo qual se pode concluir que há reconfortante consenso sobre o tema. Essa é o opinião, v.g., de Paulo

29 Luís Roberto Barroso, Interpretação e aplicação da Constituição, 2" ed., Saraiva, São Paulo, 1998 , p. 101 e ss.. O autor aponta quatro espécies de peculiaridades que singularizam as normas constitucionais: a superioridade hierárquica, a natureza da linguagem, o conteúdo específico e o caráter político.

30 Clèmerson Merlin Clève, A teoria constitucional e o direito alternativo in Uma vida dedicada ao direito - Homenagem a Carlos Henrique de Carvalho, o editor dos juristas, RT, 1995, p. 37/8.

31 Ruy Samuel Espíndola, Conceito de princípios constitucionais, RT, São Paulo, 1999, p. 105 e ss.. 
Bonavides $^{32}$, Luís Roberto Barroso ${ }^{33}$, Eros Roberto Grau ${ }^{34}$, dentre outros. Na doutrina estrangeira vale registrar as posições de Robert Alexy ${ }^{35}$, Ronald Dworkin ${ }^{36}$, Norberto Bobbio $^{37}$, Eduardo Garcia de Enterria ${ }^{38}$ e J. J. Canotilho ${ }^{39}$.

32 Paulo Bonavides, Curso de direito constitucional, 8* ed., Malheiros, São Paulo, 1999, p. 243 e ss.

33 Luís Roberto Barroso, Interpretação e aplicação da Constituição, $2^{2}$ ed., Saraiva, São Paulo, 1998 , p. 141 e ss..

34 Eros Roberto Grau, A ordem econômica na Constituiçāo de 1988 - Interpretaçāo e crítica, RT, São Paulo, 1996, p. 92 e ss..

35 Robert Alexy, Teoria de los derechos fundamentales, Trad. Emesto Garzón Valdés, Centro de Estudios Constitucionales, Madrid, 1997, p. 83: “(...) las reglas y los principios serán resumidos bajo el concepto de norma. Tanto las regras como los principios son normas porque ambos dicen lo que debe ser. Ambos pueden ser formulados com la ayuda de las expresiones deónticas básicas del mandato, la permisión y la prohibición. Los principios, al igual que las reglas, son razones para juicios concretos de deber ser (...).".

36 Ronald Dworkin, Taking rights seriously, Harvard University Press, Cambridge, Massachusetts, 1977, p.: "We might treat legal principles the way we treat legal rules and say that some principles are binding as law and must be taken into account by judges and lawyers who make decisions of legal obligation. If we took this tack, we should say that in the United States, at least, the 'law' includes principles as well as rules.". É importante registrar que o pensamento de Dworkin tem como pressuposto constante o sistema juridico norte-americano, de modo que a transposição dos raciocínios nem sempre se adequada, sem adaptações, à realidade brasileira de tradição romanogermânica.

37 Norberto Bobbio, Teoria do ordenamento juridico, Trad. Maria Celeste Cordeiro Leite dos Santos, 10 ed., Editora UNB, Brasília, 1997, p. 158/9: "A palavra principios leva a engano, tanto que é velha questão entre os juristas se os princípios gerais são normas. Para mim não há dúvida: os princípios gerais são normas como todas as outras. E esta é também a tese sustentada por Crisafulli. Para sustentar que os princípios gerais são normas, os argumentos são dois, e ambos válidos: antes de mais nada, se são normas aquelas das quais os princípios sāo extraídos, através de um procedimento de generalizaçāo sucessiva, não se vê por que não devam ser normas também eles; se abstraio da espécie animal obtenho sempre animais, e não flores ou estrelas. Em segundo lugar, a função para qual são extraídos e empregados é a mesma cumprida por todas as normas, isto é, a função de regular um caso.". Como se percebe, o autor trata do tema sob a ótica da teoria geral do direito.

38 Eduardo Garcia de Enterría, La constitucion como norma y el tribunal constitucional, 3 ed., Editorial Civitas, Madrid, 1994, p. 98/9: "no son simple retórica, no son - de nuevo hemos de impugnar esta falaz doctrina, de tanta fuerza inercial entre nosotros - simples principios 'programáticos', sin valor normativo de aplicación posible; por el contrario, son justamente la base entera del ordenamiento, la que há de prestar a éste su sentido proprio, la que há de presidir, por tanto, toda su interpretación y aplicación. (...) El carácter básico y fundamentante de estas decisiones permite incluso hablar (...) de posibles 'normas constitucionales inconstitucionales', concepto com el que se intenta subrayar, sobre todo, la primacía interpretativa absoluta de esos principios sobre los demás de la Constitución. (...) Esos principiös (...) constituyen, por ello, los principios jerárquicamente superiores para presidir a interpretación de todo el ordenamiento, comenzando por la de la Constitución misma."

39 J. J. Gomes Canotilho, Direito constitucional e teoria da Constituição, Almedina, Coimbra, 1997, p. 1.034: “(1) as regras e principios são duas espécies de normas; (2) a distinção entre regras e princípios é uma distinção entre duas espécies de normas." 
Duas são as razões normalmente apontadas para tal entendimento, do ponto de vista da dogmática constitucional. Em primeiro lugar, a própria normatividade da Constituição. Se a Constituição é norma jurídica, tudo o que nela se contém desfruta dessa natureza, reforçada ainda pelo fato de sua superioridade hierárquica sobre todo o sistema. A segunda razão diz com a própria natureza do princípio. $O$ princípio constitucional veicula normalmente uma decisão fundamental do poder constituinte originário. Não haveria sentido que o princípio, axiológica e logicamente mais relevante que a regra ${ }^{40}$, não fosse considerado norma jurídica e esta sim. A lição de Celso Antônio Bandeira de Mello já se tornou uma referência clássica que vale reproduzir, in verbis:

"Violar um princípio é muito mais grave que transgredir uma norma qualquer. A desatenção ao princípio implica ofensa não apenas a um específico mandamento obrigatório, mas a todo o sistema de comandos. É a mais grave forma de ilegalidade ou inconstitucionalidade, conforme o escalão do princípio atingido, porque representa insurgência contra todo o sistema, subversão de seus valores fundamentais, contumélia irremissivel a seu arcabouço lógico e corrosão de sua estrutura mestra." 41

O consenso termina, no entanto, quando se procura explicitar o que significa, afinal, "ser norma jurídica" ou "ter imperatividade". Isto é: qual a eficácia jurídica dos princípios (entendido por eficácia o conjunto de consequiências jurídicas que se podem manejar para buscar a realização coativa da norma desrespeitada)?

De acordo com o que se expôs no ponto anterior, se os princípios são normas jurídicas, devem pretender produzir determinados efeitos concretos que haverão de ser garantidos coativamente pela ordem jurídica. Antes, portanto, de saber como "garantir coativamente", é preciso saber "o que" será garantido.

Tome-se o princípio da dignidade da pessoa humana, formulado como fundamento da República no artigo $1^{\circ}$, III, da Constituição Federal. Parece evidente que o efeito pretendido pela norma é que as pessoas tenham uma vida digna. Saber o que é uma 'vida digna', bem como que conseqüências o ordenamento é capaz de produzir para assegurar a realização desse efeito, são dois problemas sobre os quais se cuidará adiante. Por ora, o importante é deixar registrado que, a rigor, afirmar que princípio constitucional é norma jurídica imperativa significa que o efeito por

40 Pelo princípio da unidade da Constituição, considera-se que todas as normas editadas pelo poder constituinte originário têm a mesma hierarquia. Nada obstante, não há dúvida de que se encontram no texto constitucional normas mais relevantes que outras, do ponto de vista axiológico — isto é, considerando-se os valores pelos quais o constituinte optou - e logicamente. É corrente na doutrina, v.g., que cabe aos princípios conduzir a interpretação das regras constitucionais. Veja-se sobre o ponto, Luís Roberto Barroso, Interpretação e aplicação da Constituição, $2^{\star}$ ed., Saraiva, São Paulo, 1998 , p. 145 e ss..

41 Celso Antônio Bandeira de Mello, Curso de direito administrativo, $11^{*}$ ed., Malheiros, São Paulo, 1999, p. 620. 
ele pretendido deverá ser imposto coativamente pela ordem jurídica caso não se realize espontaneamente, como se passa com as demais normas jurídicas.

Os parágrafos acima já anunciam que a questão não é tão simples como se desejaria. Se é elemento essencial da norma jurídica impor de forma obrigatória seus efeitos, nāo há dúvida que tal característica foi construída tendo como paradigma a regra, e não o princípio. A normatividade dos princípios, e especialmente dos princípios constitucionais, é fenômeno relativamente recente, como assinala Bonavides, contra uma tradição milenar das regras ${ }^{42}$. É preciso, portanto, sem abrir mão da normatividade dos princípios, reconhecer que esse é um caminho a construir ${ }^{43}$.

Pois bem. Embora evidente, o primeiro passo nesse caminho é perceber que as espécies - regra e princípio - são diferentes sob variados aspectos. A doutrina refere genericamente, v.g., que os princípios são mais abstratos que as regras, se aplicam a um número indeterminado de situações, estão mais próximos da idéia de valor e de direito etc. ${ }^{44}$ Ainda quanto a este ponto, a doutrina brasileira tem traba-

42 Paulo Bonavides, Curso de direito constitucional, $8^{*}$ ed., Malheiros, São Paulo, 1999, p. 228 e ss.. Segundo o autor, a normatividade dos princípios percorreu três fases distintas: a jusnaturalista, a positiva e a pós-positivista. Na primeira, os princípios estavam fora do direito, em um campo metafísico, associados à dimensão ético-valorativa inspiradora do direito. Na fase positivista, os princípios ingressam nos códigos e leis como fonte normativa subsidiária com a função de garantir a inteireza e coesão do sistema. Por fim, a fase pós-positivista atual, na qual os princípios constitucionais têm um papel fundamental, consagra os princípios não apenas como direito, mas como "pedestal normativo sobre o qual assenta todo o edifício jurídico dos novos sistemas constitucionais".

43 Celso Antônio Bandeira de Mello, Eficácia das normas constitucionais sobre justiça social, RDP 57-58/233: "Ao lado dos deveres e compromissos com o bem-estar público que incumbem a todos os cidadãos, os advogados são aliciados e colhidos ademais - e sobretudo - por um dever específico que advém de sua formaçāo jurídica. $O$ dever de perquirir no sistema normativo, até a exaustāo, todas as possibilidades aí abertas em prol do atendimento de valores sócio-culturais que a humanidade incorporou em seu processo civilizatório e que, bem por isso, encontram-se inevitavelmente vazados nas Cartas fundamentais dos paises do mundo civilizado." e Mauro Cappelletti, Proceso, Ideologias, Sociedad, Trad. Santiago Sentís Melendo y Tomás A. Banzhaf, Ediciones Juridicas Europa-America, Buenos Aires, 1974: “(...) constituirem os principios juridicos gerais 'normas decisórias diretamente aplicáveis', mas que apenas adquirem esse caráter 'quando se concretizam', sendo 'missão da ciência e da jurisprudência concretar esses princípios jurídicos convertendo-os em normas decisórias, estejam elas expressas ou não na Constituição ou na lei." 44 J. J. Gomes Canotilho, Direito constitucional e teoria da constituiçāo, Almedina, Coimbra, 1997, p. 1.034/5 apresenta um conjunto de critérios para a distinçāo entre regras e princípios, a saber: "a) Grau de abstraç̧āo: os princípios são normas com um grau de abstraç̧ão relativamente elevado; de modo diverso, as regras possuem uma abstracção relativamente reduzida. b) Grau de determinabilidade na aplicação do caso concreto: os princípios, por serem vagos e indeterminados, carecem de mediaçōes concretizadoras (do legislador? do Juiz?), enquanto as regras säo susceptiveis de aplicação directa. c) Grau de fundamentalidade no sistema das fontes de direito: os princípios são normas de natureza ou com um papel fundamental no ordenamento juridico devido à sua posição hierárquica no sistema das fontes (ex.: princípios constitucionais) ou à sua importância estruturante dentro do sistema jurídico (ex: princípio do Estado de Direito). d) 'Proximidade' da idéia de direito: os princípios são 'standards' juridicamente vinculantes radicados nas exigências de 'justiça' (Dworkin) ou na 'idéia de direito' (Larenz); as regras podem ser normas vinculativas 
lhado com frequiência com a distinção estrutural feita por Robert Alexy entre comandos de definição (as regras) e comandos de otimização (os princípios) ${ }^{45}$.

Com efeito, embora afirme que princípios e regras são espécies de normas, Alexy reconhece que há uma diferença qualitativa entre elas. ${ }^{46}$ Tal diferença, para o autor, está em que as normas que veiculam regras (comandos de definição) têm natureza biunívoca, isto é, só admitem duas espécies de situação, dado seu substrato fático típico: ou são válidas e se aplicam ou não se aplicam por inválidas ${ }^{47}$. Uma regra vale ou não vale juridicamente. Não são admitidas gradações.

Tudo é diferente com os princípios, denominados pelo autor de comandos de otimizaçã $o^{48}$. Ao contrário das regras, os princípios determinam que algo seja realizado na maior medida possível, admitindo uma aplicação mais ou menos ampla de acordo com as possibilidades físicas e jurídicas existentes. Estes limites jurídicos, que podem restringir a otimização de um princípio, são (i) regras que o excepcionam em algum ponto e (ii) outros princípios opostos que procuram igualmente se maximizar, daí a necessidade eventual de ponderá-los ${ }^{49}$.

Aplicando a concepção acima descrita ao pensamento de Alexy, pode-se concluir que o efeito pretendido pelo princípio poderá ser coativamente imposto na

com um conteúdo meramente funcional. e) Natureza normogenética: os princípios são fundamento de regras, isto é, são normas que estão na base ou constituem a ratio de regras juridicas, desempenhando, por isso, uma fuņ̧ão normogenética fundamentante.". Confira-se, na mesma linha, Willis Santiago Guerra Filho, Processo constitucional e direitos fundamentais, Celso Bastos Editor, São Paulo, 1999, p. 52.

45 Raquel Denize Stumm, Princípio da proporcionalidade no direito constitucional brasileiro, Livraria do Advogado Editora, Porto Alegre, 1995, p. 42 e Paulo Roberto Lyrio Pimenta, Eficácia e aplicabilidade das normas constitucionais programáticas, Max Limonad, Rio de Janeiro, 1999, p. 121 e ss.

46 Robert Alexy, Teoria de los derechos fundamentales, Trad. Emesto Garzón Valdés, Centro de Estudios Constitucionales, Madrid, 1997, p. 86: "(...) las normas pueden dividirse en reglas y principios y que entre reglas y principios existe no sólo una diferencia gradual sino cualitativa. Esta tesis es correcta."

47 Robert Alexy, Teoria de los derechos fundamentales, Trad. Ernesto Garzón Valdés, Centro de Estudios Constitucionales, Madrid, 1997, p. 88. A não aplicabilidade da regra decorre, em geral, de sua invalidade (inconstitucionalidade) ou da perda de sua vigência, como nos casos em que ela é revogada por norma hierarquicamente superior ou posterior de igual hierarquia. No caso da relação entre norma geral e especial, entretanto, a norma geral deixa de ser aplicada não por qualquer dessas duas razōes, mas porque os fatos realizam de forma específica a previsão da norma especial, que afasta a incidência da geral. Sobre os critérios de soluçâo de conflito de regras (temporal, espacial, hierárquico e por especialidade), veja-se Luís Roberto Barroso, Interpretaçāo e aplicação da constituição, 3ªd., Saraiva, São Paulo, 1999.

48 Robert Alexy, Teoria de los derechos fundamentales, Trad. Ernesto Garzón Valdés, Centro de Estudios Constitucionales, Madrid, 1997, p. 86.

49 Confira-se sobre o tema: Heinrich Scholler, $O$ principio da proporcionalidade no direito constitucional e administrativo da Alemanha, Trad. Ingo Wolfgang Sarlet, Revista Interesse Público 2, 1999, p. 93 e ss. e Daniel Sarmento, Os princípios constitucionais e a ponderação de bens in Teoria dos direitos fundamentais, Org. Ricardo Lobo Torres, Renovar, Rio de Janeiro, 1999, p. 35 e ss.. 
medida em que isso seja possível física e juridicamente, na forma referida. Assim, examinando a questão sob o ângulo da estrutura do princípio - o de um comando de otimização - esse é o seu 'potencial' normativo.

Partindo de outro ponto - não mais o da estrutura das normas, mas o de sua eficácia jurídica - a doutrina tem procurado trabalhar para expandir a capacidade normativa dos princípios. A idéia é procurar associar ao princípio as consequiências jurídicas mais eficazes possíveis para assegurar a realização do efeito por eles proposto $^{50}$.

Assim é que, atualmente, além de serem o fundamento lógico das regras em particular e do próprio sistema em geral, aos princípios se reconhece dupla eficácia: (i) eficácia interpretativa e (ii) e eficácia negativa ${ }^{51}$.

A eficácia interpretativa significa que os princípios constitucionais vão orientar a interpretação das regras em geral (não apenas as constitucionais, é bem de ver), de modo que o intérprete encontra-se obrigado a optar, dentre as possíveis exegeses da regra, aquela que realiza melhor o efeito pretendido pelo princípio constitucional pertinente. Essa espécie de conseqüência jurídica característica do princípio tem desempenhado relevante papel, v.g., na releitura do direito privado, como assinala o Professor Gustavo Tepedino, in verbis: "Diante do novo texto constitucional, forçoso parece ser para o intérprete redesenhar o tecido do direito civil à luz da nova Constituição." 52

A eficácia negativa, por sua vez, associa ao princípio a consequiência pela qual serão considerados inválidos - ou revogados, caso anteriores à promulgação da Constituição - todas as normas ou atos que o contravenham. Os dois aspectos se complementam nos casos extremos, uma vez que, se não é possível interpretar o ato ou a norma de forma a compatibilizá-los com o princípio constitucional, passa a operar a eficácia negativa para excluí-los do mundo jurídico.

50 Paulo Bonavides, Curso de direito constitucional, $8^{2}$ ed., Malheiros, São Paulo, 1999, p. 254, Luís Roberto Barroso, Interpretação e aplicação da Constituição, 2 ed., Saraiva, São Paulo, 1998, p. 146 e Ruy Samuel Espíndola, Conceito de princípios constitucionais, RT, Sāo Paulo, 1999, p. e ss..

51 Jorge Miranda, Manual de direito constitucional, vol. Il, Coimbra Editora, Coimbra, 1990, p. 220 e ss., German J. Bidart Campos, La interpretacion y el control constitucionales en la jurisdic. cion constitucional, EDIAR, Buenos Aires, 1987, p. 238 e ss., Celso Antônio Bandeira de Mello, Eficácia das normas constitucionais sobre justiça social, RDP 57-58/243 e ss., Carlos Roberto Siqueira Castro, Mandado de injunção. Limitação da taxa de juros. Eficácia das normas constitucionais programáticas. Consideraçōes acerca do art. 192, § $3^{\circ}$, da Constituição Federal, CDCDP - RT 26/97 e ss. e Luís Roberto Bartoso, Interpretação e aplicação da Constituição, $2^{*}$ ed., Saraiva, São Paulo, 1998, p. 141 e ss. e, do mesmo autor, O direito constitucional e a efetividade de suas normas, $3^{2}$ ed., Renovar, Rio de Janeiro, 1998, p. 113/114 e 288. Vale registrar que alguns dos autores referidos desenvolvem as eficácias interpretativa e negativa principalmente em relaçāo às chamadas normas programáticas, e apenas secundariamente no que diz respeito aos princípios. Sem pretender enveredar pela discussão a respeito da natureza das normas programáticas (seriam normas realmente ou princípios?), entende-se que o raciocínio utilizado para extrair delas tais modalidades de eficácia se aplica perfeitamente aos princípios.

52 Gustavo Tepedino, Premissas metodológicas para a constitucionalizaçāo do Direito Civil, in Temas de Direito Civil, Renovar, RJ, 1999, p. 13. 
Não há dúvida que essa dupla eficácia reconhecida hoje aos princípios constitucionais - interpretativa e negativa - representa um considerável avanço no esforço de construção da normatividade dos princípios, uma vez que, ainda que apenas indiretamente, procura-se assegurar, coativamente inclusive, os efeitos pretendidos pela norma. Cumpre reconhecer, entretanto, que ainda é pouco.

Tanto a eficácia interpretativa como a negativa só dispõem de meios para impedir que o princípio seja violado quando confrontados com alguma espécie de ação, normalmente estatal. A omissão que deixa de realizar o efeito do princípio escapa ao controle da eficácia interpretativa e negativa. Ocorre que não violar comissivamente não significa necessariamente realizar, salvo se todo o efeito pretendido pelo princípio puder ser alcançado através de uma abstenção ${ }^{53}$. Mesmo antes de examinar a questão mais detidamente, já se pode dizer que este não é o caso do princípio da dignidade da pessoa humana, que exige não só abstenções como ações estatais.

A questão que se coloca neste ponto é: porque os princípios não poderiam dispor da eficácia positiva típica das regras; isto é: porque não se poderia extrair diretamente dos princípios pretensões - pleiteáveis diante do Poder Judiciário - capazes de implementar de forma direta os efeitos propostos pelo princípio e não cumpridos: a consequiência jurídica perfeitamente simétrica? Porque não seria possível associar essa espécie de consequiência jurídica aos princípios constitucionais?

Retomando ainda uma vez o roteiro exposto inicialmente, ficou registrado que as normas pretendem produzir determinados efeitos e que o ordenamento cria um conjunto de conseqüências jurídicas, ou formas de eficácia, associadas para impor coativamente a realização daqueles efeitos. O primeiro problema, portanto, cuja solução é prejudicial a todos os demais, é saber que efeitos a norma pretende produzir.

Embora a primeira, essa talvez seja a maior dificuldade quando se trata de princípios e, mais ainda, quando se cuida do princípio da dignidade da pessoa humana. O Professor Luís Roberto Barroso, nada obstante ser um dos maiores divulgadores do constitucionalismo normativo brasileiro, reconhecia, desalentado, o estado da dogmática quanto ao ponto há dez anos atrás, in verbis: "Dignidade da pessoa humana é uma locução tão vaga, tão metafísica, que embora carregue em si forte carga espiritual, não tem qualquer valia jurídica." ${ }^{54}$. Nesse mesmo sentido,

53 Stephen Holmes e Cass R. Sunstein, The cost of rights, W.W. Norton \& Company, New York-London, 1999. Os autores procuraram demonstrar que a distinção corriqueira que se faz entre direitos que exigem apenas uma abstenção (direitos negativos) e os que exigem prestações estatais (direitos positivos) não corresponde a realidade, e que todos os direitos são positivos. Um exemplo utilizado na obra ajuda a esclarecer a idéia. $O$ cumprimento de uma ordem judicial determinando a desocupação de grande área rural ou urbana (tutela do direito de propriedade, que se poderia decompor do princípio da liberdade de iniciativa), exige do Estado a mobilização de policiais e viaturas, isto é, uma prestaçāo, com o correspondente custo. Desse modo, é discutível que haja princípios que demandem apenas abstençōes ou que, concretizados, produzam apenas direitos negativos.

54 Luís Roberto Barroso, $O$ Direito constitucional e a efetividade de suas normas, $3^{\text {^ }} \mathrm{ed}$., Renovar, Rio de Janeiro, 1998, p. 296. 
boa parte da doutrina registra, não sem parcela de razão, que se trata de um princípio especialmente vago e de conteúdo indeterminado ${ }^{55}$.

O desafio, portanto, está precisamente em procurar determinar o que significa dignidade da pessoa humana. Que efeitos são esses pretendidos pelo princípio que, uma vez não realizados, violam a dignidade humana, podendo ser coativamente exigidos? Isso é o que se pretende examinar no ponto seguinte.

Vale deixar registrado que, uma vez que se consiga 'concretizar', conforme recomendado pela doutrina, o efeito pretendido pela norma em questão, não haverá maior dificuldade lógica em concluir que, ao lado das eficácias interpretativa e negativa, uma das conseqüências jurídicas associadas pelo sistema constitucional à hipótese é a exigibilidade direta, diante do Estado, daquele efeito, cuja inexistência torna a vida de determinada pessoa indigna (conseqüência jurídica simétrica). A esse ponto se voltará adiante.

\section{Princípio da dignidade da pessoa humana - conteúdo}

O problema da determinação dos efeitos pretendidos pela norma-princípio que consagra a dignidade da pessoa humana deve ser examinada sob duas luzes: o da natureza e peculiaridades da própria Constituição e o do sistema especifico construído pelas normas constitucionais sobre o tema ${ }^{56}$.

\subsection{Da natureza da Constituição}

Como já se referiu, a Constituição é um documento normativo ímpar no conjunto do ordenamento por um conjunto de razões. Uma delas é que cabe à Constituição - o pressuposto com o qual se trabalha é de uma Constituição democrática realizar dois objetivos: assegurar um consenso mínimo e garantir o pluralismo político.

Em primeiro lugar, cabe à Constituição tomar determinadas decisões políticas fundamentais, dentre as quais a de garantir um mínimo de direitos aos indivíduos, que são colocadas pelo poder constituinte originário fora do alcance da deliberação política e das maiorias. A idéia que está no substrato dessa concepção, reforçada

55 Ignacio Ara Pinilla, Las transformaciones de los derechos humanos, Tecnos, Madrid, 1994, p. 32.

56 Ainda é pequena a produção brasileira específica sobre o tema. Confira-se: Fernando Ferreira dos Santos, $O$ princípio constitucional da dignidade da pessoa humana, Instituto Brasileiro de Direito Constitucional, Celso Bastos Editor, Fortaleza, 1999 e José Afonso da Silva, A dignidade da pessoa humana como valor supremo da democracia, RDA 212/89-94 (1998). Confira-se sobre o princípio na Constituição Portuguesa: José Manuel M. Cardoso da Costa, $O$ princípio da dignidade da pessoa humana na Constituiçāo e na jurisprudência constitucional portuguesas in Direito Constitucional - Estudos em homenagem a Manoel Gonçalves Ferreira Filho, Coord. Sérgio Resende de Barros e Fernando Aurelio Zilveti, Dialética, SP, 1999. 
com a experiência da Segunda Guerra Mundial, é que a democracia é mais do que a simples aplicação da regra majoritária ${ }^{57}$.

Com efeito, se a regra da maioria surge como a fórmula de viabilizar, na deliberação política, a idéia de igualdade essencial de todos os homens, não haveria qualquer sentido em permitir que o grupo majoritário, uma vez instalado no poder, tivesse liberdade tão ampla a ponto de poder se voltar contra a igualdade que lhe deu origem para violar os direitos dos membros da minoria ou para alterar a própria regra majoritária ${ }^{58}$. É indispensável, portanto, que as maiorias encontrem limites, limites estes que deverão ser fixados pela Constituição. Trata-se de pontos tão essenciais - uma espécie de consenso mínimo - que qualquer grupo que venha a exercer o poder, qualquer ideologia que venha a ser escolhida pelo povo terá de respeitá-los. Simplesmente não se admite que não o façam ${ }^{59}$.

57 Landelino Lavilla, Constitucionalidad y legalidad. Jurisdiccion constitucional y poder legislativo - Juridificación del poder y equilibrio constitucional in Division de poderes e interpretacion - Hacia una teoria de la praxia constitucional, Org. Antonio Lopes Pina, Tecnos, Madrid, 1997, p. 58, 72, Tomás de la Quadra, Metodos y criterios de interpretacion de la constitucion - La constitución como norma suprema y la seguridad jurídica in Division de poderes e interpretacion - Hacia una teoria de la praxia constitucional, Org. Antonio Lopes Pina, Tecnos, Madrid, 1997, p. 134, Franciso Fernández Segado, La teoría jurídica de los derechos fundamentales en la Constitución Española de 1978 y en su interpretación por el Tribunal Constitucional, RILSF 121, p. 77: “(...) los derechos son, simultáneamente, la conditio sine qua non del Estado constitucional democrático.", Ignacio Ara Pinilla, Las transformaciones de los derechos humanos, Tecnos, Madrid, 1994, p. 91: “(...) dos posturas igualmente insatisfactorias, la prioridad de la democracia sobre los derechos humanos, y la prioridad de los derechos humanos sobre la democracia (...) todo dependerá del significado que vayamos a atribuir al concepto de democracia. (...) Si, por el contrario, definimos la democracia como un conjunto de reglas del juego, de carácter exclusivamente procedimental (...) los derechos humanos se presentarán como un prius lógico com relación a ala democracia." e Tomás de la Quadra, Interpretacion de la constitucion y organos del estado in Division de poderes e interpretacion - Hacia una teoria de la praxia constitucional, Org. Antonio Lopes Pina, Tecnos, Madrid, 1997, p. 34: “La Constitución, para la actividad politica, es un fundamento y un marco de referencia dentro del cual puede y debe moverse com libertad. La Constitución, en cambio, para el órgano constitucional encargado de velar por su aplicación, es la norma minima a respetar;"

58 Jorge Hage Sobrinho, "Democracy and distrust - A Theory of judicial review" - John Hart Ely: resumo e breves anotações à luz da doutrina contemporânea sobre interpretação constitucional, Arquivos do Ministério da Justiça, 48 (186)/201-225, jul/dez, 1995, p. 203, 209.

59 Pedro Cruz Villalón, Legitimidade da justiça constitucional e princípio da maioria in Legitimidade e legitimação da justiça constitucional - Colóquio no $10^{\circ}$ aniversário do Tribunal Constitucional, Coimbra Editora, Coimbra, 1995, p. 86 e ss., Francisco Lucas Pires, Legitimidade da justiça constitucional e princípio da maioria in Legitimidade e legitimação da justiça constitucional - Colóquio no $10^{\circ}$ aniversário do Tribunal Constitucional, Coimbra Editora, Coimbra, 1995, p. 170 e J. J. Gomes Canotilho, Direito constitucional e teoria da constituição, Almedina, Coimbra, 1997, p. 311: "A democracia tem como suporte ineliminável o princípio maioritário, mas isso nāo significa qualquer 'absolutismo da maioria' $e$, muito menos, o domínio da maioria. $O$ direito da maioria é sempre um direito em concorrência com o direito das minorias com o conseqüiente reconhecimento de estas se poderem tornar maiorias.

A maioria não pode dispor de toda a 'legalidade', ou seja, não the está facultado, pelo simples 
Na outra ponta, o segundo objetivo de uma Constituição democrática é assegurar o pluralismo político, consagrado no inciso $\mathrm{V}$, do art. $1^{\circ}$ da Constituição brasileira de 1988. Isto é: garantir a abertura do sistema e o exercício democrático de modo que o povo possa, a cada momento, decidir qual o caminho a seguir ${ }^{60}$.

Os dois objetivos se encontram na medida em que qualquer opção que o povo faça terá necessariamente de respeitar aquele consenso mínimo assegurado pela Constituição. Note-se que essas normas básicas intangíveis têm também um papel fundamental de garantir o regular funcionamento do próprio mecanismo democrático, de modo a impedir que uma maioria venha a destruí-lo. Por outro lado, não cabe à Carta definir de forma integral e definitiva a respeito da vida política do povo, o que caberá a este mesmo, a cada nova oportunidade eleitoral.

A fórmula encontrada pela Constituição Federal de 1988 para compatibilizar os dois objetivos foi a garantia de ampla participação democrática, principalmente por meio de eleições diretas e periódicas em todos os níveis ${ }^{61}$. Por outro lado, estão vedadas à apreciação legislativa, inclusive na forma de emenda à Constituição, as conhecidas cláusulas pétreas, listadas no art. $60, \S 4^{\circ}$, a saber: a forma federativa de Estado; o voto direto, secreto, universal e periódico, a separação dos Poderes e os direitos e garantias individuais.

Ora bem. Em que medida toda essa particularidade da natureza da Constituição acima exposta se relaciona com o princípio da dignidade da pessoa humana? É que o princípio da dignidade da pessoa humana, em função de sua amplitude, ocupa espaços naqueles dois campos: o do consenso mínimo e o da liberdade democrática. Explica-se.

Têm razão os autores quando dizem que sob o manto do princípio da dignidade da pessoa humana podem abrigar-se as concepçōes mais diversas: a defesa e a condenação do aborto, a defesa e a condenação da eutanásia, o liberalismo e o dirigismo econômico etc. Esse é o campo reservado à deliberação democrática. Por isso é que não cabe ao Judiciário simplesmente formular um conteúdo completo da

facto de ser maioria, tornar disponível o que é indisponível, como acontece, por ex., com os direitos, liberdades e garantias e, em geral, com toda a disciplina constitucionalmente fixada (o princípio da constitucionalidade subrepōe-se ao princípio maioritário."

60 Tomás de la Quadra, Metodos y criterios de interpretacion de la constitucion - La constitución como norma suprema y la seguridad juridica in Division de poderes e interpretacion - Hacia una teoria de la praxia constitucional, Org. Antonio Lopes Pina, Tecnos, Madrid, 1997, p. 136: “Es evidente que esse pluralismo político está dirigido a que las distintas concepciones ideológicas o políticas que existen en la sociedade tengan la oportunidad de plasmar su concepción particular acerca de los valores superiores de libertad, justicia e igualdad. Es evidente que hay un núcleo esencial de esos valores y de los derechos fundamentales que deben ser respetados por cualesquiera de estas opciones."

61 Os artigos 44 a 46 cuidam da eleição e mandato de deputados federais e senadores e os 77 e 82 da eleição e mandato do Presidente da República e Vice. Os artigos 27 e 28 tratam do mesmo assunto com relação a deputados estaduais e governadores e o artigo 29 com referência a vereadores e prefeitos. No art. 14 se encontram as condições para $o$ alistamento eleitoral e para a elegibilidade dos diversos cargos. 
dignidade que lhe pareça mais adequado, como faz, v.g., com o conceito de 'mulher honesta'. Essa é a esfera do político e faz parte das particularidades da Constituição garantir que esse campo lhe seja reservado.

Nada obstante, se o princípio se resumisse a isso - ao que cabe ao Legislativo deliberar - não haveria necessidade de prevê-lo na Constituição, nem sentido em dizer que se trata de uma norma jurídica dotada de imperatividade. Voltaríamos ao tempo em que as normas constitucionais eram meros programas dirigidos exclusivamente ao Legislador.

Ao lado do campo meramente político, uma fração do princípio da dignidade da pessoa humana, seu conteúdo mais essencial, está contido naquela esfera do consenso mínimo assegurada pela Constituição e transformada em terreno jurídico. É precisamente aqui que reside a normatividade do princípio constitucional.

Note-se que a conclusão a que se chega se aproxima daquela formulada por Robert Alexy ${ }^{\wedge 2}$, referida acima. Para o autor, a aplicação de um princípio (comando de otimização) poderá ser restringida por outros princípios, embora haja um mínimo sem o qual o princípio é considerado violado. Aplicando o raciocínio ao princípio da dignidade da pessoa humana, Alexy vai ponderá-lo com três outras idéias: a separação dos Poderes, a competência do legislador democrático e os direitos de terceiros. A conclusão do autor é que estes três pontos restringem o princípio da dignidade mas apenas em determinada medida, restando como conteúdo normativo do princípio, que o autor inclusive considera transformar-se em regra, um mínimo essencial para a existência humana que pode ser exigido diante do Poder Judiciário.

Voltando ao ponto, uma boa imagem do princípio da dignidade da pessoa humana pode ser a de dois círculos concêntricos. $O$ círculo interior cuida desse mínimo de dignidade, decisão fundamental do poder constituinte originário, que qualquer maioria terá de respeitar, e que, afinal, representa o efeito concreto pretendido pela norma e exigível. $O$ espaço entre o círculo interno e o externo será ocupado pela deliberação política ${ }^{63}$.

Não é necessário, portanto, determinar todo o conteúdo do princípio, ou todas as suas pretensões, uma vez que o princípio da dignidade humana contém, de fato, um campo livre para a deliberação política, mas é possível e desejável apurar esse núcleo mínimo de efeitos pretendidos, de modo a maximizar sua normatividade ${ }^{64}$. Mas que conteúdo mínimo é esse?

62 Robert Alexy, Teoria de los derechos fundamentales, Trad. Ernesto Garzón Valdés, Centro de Estudios Constitucionales, Madrid, 1997, p 494 e ss..

63 Jorge Rodríguez-Zapata, Metodos y criterios de interpretación da la Constitución en los seis primeros años de actividad del Tribunal Constitucional in Division de poderes e interpretacion Hacia una teoria de la praxia constitucional, Org. Antonio Lopes Pina, Tecnos, Madrid, 1997, p. 157.

64 Franciso Fernández Segado, La teoría jurídica de los derechos fundamentales en la Constitución Española de 1978 y en su interpretación por el Tribunal Constitucional, RILSF 121, p. 80: "Cuando la Norma Suprema opera com arreglo a esa técnica, por la que se reserva al legislador la configuración del derecho, el mandato constitucional puede no tener, hasta que la regulación se produzca, más que un mínimo contenido, pero esse mínimo contenido há de ser protegido (...)." 
O novo problema consiste em determinar que conteúdo mínimo é esse, que nada mais é do que saber que efeitos concretos - agora já restritos ao tal mínimo - o princípio pretende produzir, de modo que, caso eles não se realizem, seja possível impor seu cumprimento coativamente.

Os céticos poderiam supor que apenas se substituiu a imprecisão do termo 'dignidade humana' por outro igualmente indefinido: 'conteúdo mínimo de dignidade'. Não é verdade.

Embora não se tenha qualquer pretensão de exaustividade ou definitividade, há, em primeiro lugar, um consenso lógico - metajurídico, porque não? - a respeito do assunto ${ }^{65}$. Não há quem possa, com seriedade intelectual, afirmar, por exemplo, que uma pessoa tem sua dignidade respeitada se não tiver o que comer ou com o que vestir, se não tiver oportunidade de ser alfabetizada, se não dispuser de alguma forma de abrigo. Luís Roberto Barroso, embora, à época, descrente das possibilidades jurídicas do princípio, deixou registrado, in verbis:

"Dignidade da pessoa humana é uma locução tão vaga, tão metafísica, que embora carregue em si forte carga espiritual, não tem qualquer valia jurídica. Passar fome, dormir ao relento, nāo conseguir emprego são, por certo, situações ofensivas à dignidade humana." 66 (itálico acrescentado)

Registre-se desde logo que também fazem parte desse conteúdo mínimo da dignidade os chamados direitos da liberdade, v.g., liberdade de expressão, liberdade religiosa, liberdade de locomoção, direito de propriedade etc.. O tema não será tratado aqui especificamente. Não por desprestígio, mas apenas porque a normatividade desses direitos já se encontra definitivamente consolidada nos textos consti-

65 Konrad Hesse, Elementos de direito constitucional da República Federal da Alemanha, Trad. Luís Afonso Heck, Sergio Antonio Fabris Editor, Porto Alegre, 1998, p. 61: "Interpretação constitucional é concretização. Exatamente aquilo que, como conteúdo da Constituição, ainda não é univoco deve ser determinado sob inclusão da 'realidade' a ser ordenada (supra, número de margem 45 e seguinte). Nesse aspecto, interpretaçāo jurídica tem caráter criador: o conteúdo da norma interpretada conclui-se primeiro na interpretação; naturalmente, ela tem também somente nesse aspecto caráter criador; a atividade interpretativa permanece vinculada à norma. (...) $O$ intérprete não pode compreender o conteúdo da norma de um ponto situado fora da existência histórica, por se assim dizer, arquimédico, senão somente na situação histórica concreta, na qual ele se encontra, cuja maturidade enformou seus conteúdos de pensamento e determina seu saber e seu (pré)-juizo. Ele entende o conteúdo da norma de uma (pré)-compreensão (...)" e Celso Antônio Bandeira de Mello, Eficácia das normas constitucionais sobre justiça social, RDP 57-58/249: "Nem se diga que está em pauta conceito vago, fluído, impreciso e por isso carente de especificação legal. Já se anotou que os conceitos desta ordem são comuns nas regras jurídicas e têm, todos eles, um núcleo significativo estrem de dúvidas. Por isso ao Judiciário cabe conhecer de seu alcance para aplicação do Direito no caso concreto. Não há de supor que a inteligência judicial seja, de direito, e muito menos de fato, desamparada de luzes bastantes para extrair deste preceito a dimensão que tem." (itálico acrescentado).

66 Luís Roberto Barroso, $O$ Direito constitucional e a efetividade de suas normas, $3^{2}$ ed., Renovar, Rio de Janeiro, 1998, p. 296. 
tucionais, existindo inclusive todo um instrumental processual específico para sua tutela. Mais importante a essa altura é saber que outros direitos — correspondentes a outros efeitos pretendidos pelo princípio - estão contidos no conteúdo mínimo da dignidade da pessoa humana.

Ainda persistindo na idéia do consenso lógico, imagine-se a situação totalmente insólita de uma lei estabelecendo que um determinado grupo de pessoas - os ciganos, v.g., o que já vale como uma referência histórica — não poderiam ser alfabetizados ou não poderiam comprar ou alugar qualquer espécie de imóvel no território nacional. Desconsiderando-se outros princípios constitucionais que também seriam violados, não há dúvida de que a eficácia negativa do princípio da dignidade da pessoa humana conduziria tal norma à invalidade. E por que? Porque, de acordo com o consenso, uma norma desse teor estaria afrontando elementos por demais básicos da dignidade humana. Note-se, portanto, que a idéia do mínimo já se encontra subjacente à aplicação da eficácia negativa, generalizadamente aceita pela doutrina ${ }^{67}$.

O Professor Ricardo Lobo Torres é um dos poucos a cuidar do tema entre nós. Em sua visão, esse mínimo (denominado mínimo existencial) representa um conjunto de condições iniciais para o exercício da liberdade. $O$ próprio autor esclarece:

"Sem o mínimo necessário à existência cessa a possibilidade de sobrevivência do homem e desaparecem as condições iniciais da liberdade. A dignidade humana e as condições materiais da existência não podem retroceder aquém de um mínimo." 68

67 As Constituições alemã, portuguesa e espanhola, a esse propósito, fazem referência expressa à proteçāo desse "conteúdo essencial" dos direitos fundamentais, como refere Suzana de Toledo Barros, $O$ princípio da proporcionalidade e o controle de constitucionalidade das leis restritivas de direitos fundamentais, Brasília Jurídica, Brasilia, DF, p. 94: "A Constituiçāo alemã inseriu-o no art. 19.2, prescrevendo que 'em nenhum caso um direito fundamental poderá ser afetado em sua essência'. A Constituiçāo Portuguesa refere-se à garantia do núcleo essencial em seu art. 18.3, segundo o qual 'as leis restritivas de direitos, liberdades e garantias têm de revestir caráter geral $e$ abstracto e não podem ter efeito retroactivo nem diminuir a extensāo e o alcance do 'conteúdo essencial' dos preceitos constitucionais'. $O$ art. 53.1 da Constituição espanhola também alude à garantia, ao estabelecer que os 'direitos e liberdades reconhecidos no Capítulo II do presente Título vinculam todos os poderes públicos. Somente por lei, que em todos os casos deve respeitar seu 'conteúdo essencial', poderâo ser regulados esses direitos e liberdades (...)'.". (negrito no original) e Juan Carlos Gavara de Cara, Derechos Fundamentales y desarrollo legislativo - La garantía del contenido esencial de los derechos fundamentales en la Ley Fundamental de Bonn, Centro de estudios constitucionales, Madrid, 1994, p. 227, 347: "Esta tesis del ámbito nuclear implica distinguir dentro del derecho fundamental la existencia de un contenido esencial que será el NÚCLEO o círculo interno del derecho fundamental y un contenido accidental que sería la PERIFERIA o elemento exterior del derecho fundamental. (...) contenido esencial de un derecho aquela parte del mismo que es ineludiblemente necesaria para que el derecho permita a su titular la satisfacción de aquellos intereses para cuja consecución el derecho se otorga." (grifos no original).

68 Ricardo Lobo Torres, Os direitos humanos e a tributação - Imunidades e isonomia, Renovar, RJ, 1995, p. 129. 
Ao concretizar o ponto, o ilustre professor conclui:

"Os direitos à alimentação, saúde e educação, embora não sejam originariamente fundamentais, adquirem o status daqueles no que concerne à parcela mínima sem a qual o homem não sobrevive." ${ }^{69}$

\section{J. J. Gomes Canotilho também aborda a questão nesses termos, in verbis:}

"Das várias normas sociais, económicas e culturais é possível deduzir-se um principio jurídico estruturante de toda a ordem económico-social portuguesa: todos (princípio da universalidade) têm um direito fundamental a um 'núcleo básico de direitos sociais' (minimum core of economic and social rights), na ausência do qual o estado português se deve considerar infractor das obrigações jurídico-sociais constitucional e internacionalmente impostas. Nesta perspecti$v a$, o 'rendimento mínimo garantido', as 'prestaçōes de assistência social básica', o 'subsídio de desemprego' são verdadeiros direitos sociais originariamente derivados da constituição sempre que eles constituam o standard mínimo de existência indispensável à fruição de qualquer direito. "70 (grifos no original)

É possível, portanto, extrair do consenso esses outros direitos do conteúdo mínimo da dignidade da pessoa humana. Nada obstante isso, e para tranquiilidade da nossa tradição positivista, a própria Constituição Federal de 1988 preocupou-se, ao longo do texto, em concretizar o princípio da dignidade que havia previsto inicialmente, indicando patamares mínimos e campos a serem desenvolvidos. Confira-se.

\subsection{O Sistema constitucional em vigor}

Além dos direitos já consagrados no art. $5^{\circ}$, chamados comumente de direitos individuais, há outros direitos previstos na Constituição, pertencentes a outras categorias (direitos sociais, econômicos e sociais, normalmente), que vão dar forma ao menos uma fração deles o fará - ao conteúdo mínimo da dignidade ${ }^{71}$. Lembre-se,

69 Ricardo Lobo Torres, Os direitos humanos e a tributação - Imunidades e isonomia, Renovar, RJ, 1995, p. 133.

70 J. J. Gomes Canotilho, Direito constitucional e teoria da constituição, Almedina, Coimbra, 1997, p. 470.

71 Francis Delpérée, $O$ direito à dignidade humana in Direito Constitucional - Estudos em homenagem a Manoel Gonçalves Ferreira Filho, Coord. Sérgio Resende de Barros e Fernando Aurelio Zilveti, Dialética, SP, 1999, p.. 154: "De um lado, a Constituição [o autor refere-se à Constituição belga, em sua redação atual] concede - de maneira concreta - a todos os homens, direitos específicos e, para resumir, minimos. É o início dos direitos da personalidade. A um ponto tal que, se o individuo não dispōe -- de direito ou de fato - de tal condição, ele se encontra em uma situação de indignidade efetivamente." 
por muito importante, que o princípio da dignidade da pessoa humana deverá presidir a interpretação de todas essas normas e do texto constitucional como um todo ${ }^{72}$

Embora não se vá tratar dos direitos chamados individuais, vale destacar desse grupo, pela importância para os fins aqui propostos, o amplo direito de acesso ao Poder Judiciário para tutela de situações individuais (ou coletivas), consagrado no art. $5^{\circ}, \mathrm{XXXV}$. Como já referido, a impossibilidade eventual de utilizar-se - por falta de informação, falta de recursos, ou qualquer outra forma de carência - dos meios de tutela dos direitos acaba por inviabilizar na prática a sua imperatividade. Nada terá adiantado identificar o efeito normativo e a conseqüência jurídica capaz de realizá-lo se não se puder levar tudo isso ao Judiciário ${ }^{73}$.

Voltando àqueles outros direitos que, juntamente com os individuais, vão compor o mínimo de dignidade, uma proposta de sistematização ${ }^{74}$ com os olhos voltados para a própria Carta de 1988 deveria envolver três categorias de direitos, como efeitos necessários do conteúdo mínimo da dignidade humana: educação fundamental, saúde mínima e assistência aos desamparados.

Em primeiro lugar, vale referir o direito à educação fundamental, a cargo especificamente dos municípios, na forma do artigo 30, VI da Constituição. Com efeito, além da previsão do art. 205 ("Art. 205. A educação, direito de todos e dever do Estado e da família (...)), o art. 208 é bastante claro sobre o ponto, in verbis:

\footnotetext{
“Art. 208. O dever do Estado com a educação será efetivado mediante a garantia de:

I - ensino fundamental obrigatório e gratuito, assegurada, inclusive, sua oferta gratuita para todos os que a ele não tiverem acesso na idade própria; II - progressiva universalização do ensino médio gratuito; (...) $\S 1^{\circ}$. O acesso ao ensino obrigatório e gratuito é direito público subjetivo."
}

72 Eduardo Garcia de Entería, La constitucion como norma y el tribunal constitucional, $3^{2}$ ed., Editorial Civitas, Madrid, 1994, p. 98/9, Luís Roberto Barroso, Interpretação e aplicação da Constituição, 2 ed., Saraiva, São Paulo, 1998, p. 141 e 145: "O ponto de partida do intérprete há que ser sempre os princípios constitucionais, que são o conjunto de normas que espelham a ideologia da Constituição, seus postulados básicos e seus fins. (...) A atividade de interpretação da Constituição deve começar pela identificação do principio maior que rege o tema a ser apreciado, descendo do mais genérico ao mais específico, até chegar à formulação da regra concreta que vai reger a espécie. (...) Esses princípios constitucionais fundamentais, exprimindo, como já se disse, a ideologia política que permeia o ordenamento jurídico (...) são dotados de natural força de expansão, comportando desdobramentos em outros princípios e em ampla integração infraconstitucional." e J. J. Gomes Canotilho, Direito constitucional e teoria da constituição, Almedina, Coimbra, 1997, p. 1.048/9: "Os princípios estruturantes não são apenas densificados por princípios constitucionais gerais ou especiais. A sua concretização é feita também por várias regras constitucionais, qualquer que seja a sua natureza."

73 Para um estudo sobre o problema do acesso à justiça do ponto de vista individual e coletivo, confira-se: Paulo Cezar Pinheiro Carneiro, Acesso à justiça - Juizados especiais e ação civil pública, Forense, Rio de Janeiro, 1999.

74 Que nada mais é do que isso mesmo: apenas uma proposta, um registro para reflexão. 
É interessante verificar que a própria Constituição adota a distinção acima enunciada do princípio da dignidade em um núcleo jurisdicionalizado - ensino fundamental, no caso - e o remanescente deixado à competência do Legislador progressiva universalização do ensino médio gratuito etc. ${ }^{75}$.

$\mathrm{O}$ efeito pretendido pela norma, portanto, é que todas as pessoas tenham acesso gratuito ao ensino fundamental. Caso isso não se verifique, no entanto, qual a consequiência? A consequiência jurídica simétrica usual: torna-se exigível do Estado, por meio do Poder Judiciário, o efeito/direito não realizado.

Note-se que não é necessário que a Constituição enuncie de forma específica essa consequiência, assim como não é necessário que a Lei 8.078/90 diga que os consumidores que firmaram um contrato de financiamento no qual estejam sendo praticados juros moratórios superiores a $2 \%$ poderão dirigir-se ao Judiciário para ver seu direito tutelado. Essa é a consequiência natural da frustração de qualquer efeito normativo, mais ainda quando esse efeito se consubstancia em um direito, como decorre do próprio art. $5^{\circ}, \mathrm{XXXV}$ acima referido.

A Constituição ocupou-se, no entanto, de especificar o contorno dessa consequiência jurídica simétrica, in verbis:

“Art. 213. Os recursos públicos serāo destinados às escolas públicas, podendo ser dirigidos a escolas comunitárias, confessionais ou filantrópicas, definidas em lei, que:

(...)

$\S 1^{\circ}$. Os recursos de que trata este artigo poderão ser destinados a bolsas de estudo para o ensino fundamental e médio, na forma da lei, para os que demonstrarem insuficiência de recursos, quando houver falta de vagas e cursos regulares da rede pública na localidade da residência do educando, ficando o Poder Público obrigado a investir prioritariamente na expansão de sua rede na localidade."

Assim, de acordo com o texto constitucional, é exigível do Estado, relativamente ao ensino fundamental, bolsa de estudo em escola que não pertença a rede pública quando esta não dispuser de vagas na localidade de residência do educando, até que as vagas sejam criadas pelo Poder Público ${ }^{76}$. Ou seja: o Estado estará obrigado a

$75 \mathrm{O}$ mesmo acontece, v.g., entre os parágrafos $1^{\circ} \mathrm{e} 2^{\circ}$ do art. 213, in verbis:

" $\$ 1^{\circ}$. Os recursos de que trata este artigo poderão ser destinados a bolsas de estudo para o ensino fundamental e médio, na forma da lei, para os que demonstrarem insuficiência de recursos, quando houver falta de vagas e cursos regulares da rede pública na localidade da residência do educando, ficando o Poder Público obrigado a investir prioritariamente na expansão de sua rede na localidade.

$\S 2^{\circ}$. As atividades universitárias de pesquisa e extensāo poderäo receber apoio financeiro do Poder Público."

76 Esta também a opinião de Luís Roberto Barroso, $O$ direito constitucional e a efetividade de suas normas, 3" ed., Renovar, Rio de Janeiro, 1998, p. 106/7: “De qual dos 'direitos' se está aqui tratando? Dos da Segunda espécie, valendo a norma como um programa a ser progressivamente implementado ao talante do Poder Público? Ou, ao revés, poderia um chefe de familia carente, 
custear a formação fundamental do indivíduo em estabelecimento privado, enquanto não colocar à disposição ensino público fundamental gratuito ${ }^{77}$.

A Constituição cuidou ainda de associar um conjunto de outras consequiências jurídicas, de natureza totalmente diversa, à violação desse efeito pretendido (e para tanto o faz expressamente). Assim é que: (i) a autoridade competente será responsabilizada pelo não oferecimento do ensino obrigatório ou pelo seu oferecimento irregular (art. 208, $\left.\S 2^{\circ}\right)^{78}$ e (ii) União poderá intervir nos Estados quando estes não houverem aplicado no ensino o percentual mínimo da receita dos impostos previstos na Constituição, e o mesmo poderão fazer os Estados em relação aos Municípios (arts. 212 caput e $\S 3^{\circ}, 34$, VII, " $e$ " e 35, III) $)^{79}$.

Em segundo lugar, tem-se a saúde mínima. A Constituição, com efeito, prevê em seu art. 196:

"Art. 196. A saúde é direito de todos e dever do Estado, garantido mediante políticas sociais e econômicas que visem à redução do risco de doença e de outros agravos e ao acesso universal igualitário às ações e serviços para sua promoção, proteção e recuperação."

em região onde não haja uma escola pública, exigir que o Estado custeasse os estudos de seu filho de dez anos em uma escola privada? Parece-me, definitivamente, que a segunda posição é a correta." Veja-se também sobre o tema Nina Beatriz Stocco Ranieri, Direito ao desenvolvimento e direito a educação - relações de realização e tutela, RDCCP - RT 6/124 e ss..

77 É claro que será preciso desenvolver um conjunto de critérios para orientar a decisão do juiz nesse mister. Dentre diversas escolas eventualmente existentes na localidade, com os custos mais variados, em qual deverá o juiz matricular o educando? Uma idéia seria orientar a escolha pela equivalência de custos, a saber: apurado o custo que o Estado teria com o aluno em uma escola pública, deveria ser escolhida a escola que mais ser aproxime desse custo, por exemplo.

78 "Art. 208.

$\S 2^{\circ}$. O não-oferecimento do ensino obrigatório pelo Poder Público, ou sua oferta irregular, importa responsabilidade da autoridade competente."

79 "Art. 212. A União aplicará, anualmente, nunca menos de dezoito, e os Estado, o Distrito Federal e os Municípios vinte e cinco por cento, no mínimo, da receita resultante de impostos, compreendida a proveniente de transferências, na manutenção e desenvolvimento do ensino.

$\S 3^{\circ}$. A distribuição dos recursos públicos assegurará prioridade ao atendimento das necessidades do ensino obrigatório, nos termos do plano nacional de educação."

“Art. 34. A União nāo intervirá nos Estado nem no Distrito Federal, exceto para:

VII - assegurar a observância dos seguintes princípios constitucionais:

e) aplicação do mínimo exigido da receita resultante de impostos estaduais, compreendida a proveniente de transferências, na manutenção e desenvolvimento do ensino."

Art. 35. O Estado não intervirá em seus Municípios, nem a União nos Municípios localizados em Território Federal, exceto quando:

III - não tiver sido aplicado o mínimo exigido da receita municipal na manutenção e desenvolvimento do ensino;" 
O art. 198 enuncia uma distinção, ainda que de forma um tanto vaga, entre o conteúdo mínimo da saúde e que será objeto do debate político. Confira-se, in verbis:

"Art. 198. As ações e serviços públicos de saúde integram uma rede regionalizada e hierarquizada e constituem um sistema único, organizado de acordo com as seguintes diretrizes:

II - atendimento integral, com prioridade para as atividades preventivas, sem prejuizo dos serviços assistenciais;"

Salvo por previsões específicas ${ }^{80}$, é preciso reconhecer que o texto constitucional não oferece todas as respostas para delimitar o que é saúde mínima e, portanto, qual o conjunto de efeitos mínimos que deriva do dignidade humana no que diz respeito à saúde. Isso não significa, no entanto, que não se possa construir tal distinção, inclusive com apoio interdisciplinar em estudos médicos. Um critério, no entanto, foi indicado pela Constituição: as atividades preventivas (v.g., saneamento básico — arts. 23, IX e 200, IV - e vacinação preventiva) hão de ter prioridade. O professor Ricardo Lobo Torres procurou enfrentar o assunto nessa linha, in verbis:

" $A C F$ distinguiu, sem a menor dúvida, entre as prestações de saúde que constituem proteção do mínimo existencial e das condiçōes necessárias à existência, que são gratuitas, e as que se classificam como direitos sociais e que podem ser custeadas por contribuições (medicina curativa). De feito, as atividades preventivas geram o direito ao atendimento integral e gratuito: as campanhas de vacinação, a erradicação das doenças endêmicas e o combate às epidemias são obrigações básicas do Estado, deles se beneficiando ricos e pobres independentemente de qualquer pagamento. (...) O grande problema do 'direito à saúde', por conseguinte, é definir os limites dentre nos quais é considerado direito fundamental, gerando a obrigatoriedade da prestação estatal gratuita, ou mero direito social, fora do campo do mínimo existencial." 81

Assim, será necessário elaborar alguns critérios para definir que prestações de saúde serão parte da saúde mínima e por isso exigíveis. Além do caráter preventivo, fixado pela Constituição, um outro elemento que pode orientar a decisão é o número de pessoas afetadas pelo problema, ou melhor: a capacidade da questão de saúde afetar de forma generalizada e indiscriminada a população. A questão, evidentemente, está longe de ser simples. Fica o registro para desenvolvimento posterior.

Por fim, o último efeito que se quer referir deve derivar do conteúdo mínimo da dignidade é a assistência aos desamparados, prevista no art. $6^{\circ}$ da Carta ${ }^{82}$. Trata-se

80 Este é o caso da proteção à gestante e à maternidade: "Art. 201. (...) I — proteçāo à maternidade, especialmente à gestante.". Veja-se também 0 art. $6^{\circ}$, caput.

81 Ricardo Lobo Torres, Os direitos humanos e a tributação - Imunidades e isonomia, Renovar, RJ, 1995, p. 147/8. 
de viabilizar para quem quer que esteja completamente desamparado alguma espécie de auxílio que supra suas necessidades básicas de comer, vestir e abrigar-se ${ }^{\mathrm{R3}}$.

A Constituição já prevê as hipóteses de seguro-desemprego (art. $7^{\circ}$, II) e da assistência social. Esta será prestada, na forma constitucional, a quem necessitar, independentemente de contribuição, especialmente para a promoção da integração ao mercado de trabalho (art. 203, III), bem como mediante o pagamento de um salário-mínimo mensal para a garantia de sobrevivência do idoso e do deficiente que não tenham condições de prover à sua própria manutenção ou de tê-la provida por sua família (art. 203, V).

Embora se cuide de medidas pontuais, elas representam um conjunto mínimo de efeitos que poderá ser cumprido coativamente mediante a intervenção do Poder Judiciário.

Vale notar, à guisa de conclusão, que esses três direitos - ensino fundamental, saúde mínima e assistência aos desamparados - não foram escolhidos aleatoriamente. A primeira razão para a escolha foi, evidentemente, que a própria Constituição trata deles de forma específica. Nada obstante, os três pontos se justificam logicamente. A saúde mínima se relaciona de forma muito próxima com o direito à vida, sendo dela quase indissociável. A educação fundamental é pressuposto essencial na formação de cidadãos capazes de participar de uma democracia, bem como na capacitação mínima para o trabalho. Negá-la a quem quer que seja significa alijar o indivíduo da participação democrática bem como condená-lo quase certamente à miséria. $\mathrm{O}$ assistência aos desamparados é o recurso último para impedir que alguém ultrapasse a linha da miséria absoluta e da indignidade.

\section{Conclusão}

O presente trabalho, ainda que singelamente, pretendeu contribuir para dar maior densidade jurídica às noções de normatividade e imperatividade das normas consti-

82 "Art. $6^{\circ}$. São direitos sociais a educação, a saúde, o trabalho, o lazer, a segurança, a previdência social, a proteção à maternidade e à infância, a assistência aos desamparados, na forma desta Constituição." (grifo acrescentado).

83 A Corte de arbitragem belga já se pronunciou acerca da natureza das prestações de assistência aos desamparados, como registra Francis Delpérée, $O$ direito à dignidade humana in Direito Constitucional - Estudos em homenagem a Manoel Gonçalves Ferreira Filho, Coord. Sérgio Resende de Barros e Fernando Aurelio Zilveti, Dialética, SP, 1999: p. 156/7: "O direito à vida pode requerer um mínimo de meios de subsistência. Esta é a razão pela qual uma assistência social é outorgada com base na lei de 8 de julho de 1976. O objetivo, determina em termos expressos a lei, é que o beneficiário possa levar uma vida de acordo com a dignidade humana. (...) Convidada a se pronunciar sobre o alcance da legislação relativa à assistência social, a Corte de Arbitragem considerou que o legislador - e, por via de conseqüência, o constituinte - quiseram indicar um começo, aquém do qual a vida do individuo não estaria mais em conformidade com as exigências da dignidade humana. É isto que explica, por exemplo, que o legislador garanta 'o caráter intangível e inalienável das quantias outorgadas a título de assistência social', mesmo em relação aos credores de alimentos." 
tucionais em geral, dos princípios em particular e, de forma mais específica, do princípio da dignidade da pessoa humana, inscrito na Constituição de 1988 , art. $1^{\circ}$, III, como fundamento da República Federativa do Brasil.

Nesse sentido, procurou-se agregar elementos ao esforço empreendido pela doutrina na construção da normatividade da Constituição, especialmente no que diz respeito àquelas decisões fundamentais do constituinte originário a respeito da dignidade mínima do ser humano, de modo a delimitar as fronteiras do jurídico e do político na matéria. Assim, em desfecho de tudo que se expôs, é possível compendiar as idéias básicas do trabalho em algumas proposições objetivas na forma que segue.

1) A norma jurídica tem como elemento essencial a imperatividade, isto é: a capacidade de impor coativamente, se necessário, a realização dos efeitos por ela propostos. Tomando-se uma norma, é preciso identificar, portanto: (i) qual o efeito que ela pretende produzir e (ii) que consequiência jurídica (ou modalidades de eficácia) o ordenamento associa a tal norma para produzir o efeito inicialmente previsto. Vale lembrar que a espécie mais freqüente de consequiência jurídica criada pelo ordenamento é a perfeitamente simétrica, pela qual se assegura àquele que seria beneficiado com a produção espontânea do efeito normativo, o direito de exigir diante do Poder Judiciário esse mesmo benefício. Além desses dois elementos é preciso também que exista um meio de tutela jurisdicional hábil para implementar a consequiência jurídica e realizar o efeito da norma.

2) As normas constitucionais - regras e princípios - são normas jurídicas, ainda que apresentem um conjunto de especificidades. Assim, hão de compartilhar com as normas jurídicas em geral dessa característica essencial que é a imperatividade.

3) O estado atual da doutrina reconhece aos princípios duas modalidades de eficácia (ou espécies de consequiências jurídicas): a interpretativa e a negativa. Eficácia interpretativa significa que os princípios constitucionais vão orientar a interpretação das regras em geral, obrigando o intérprete a optar pela exegese que melhor realize o efeito pretendido pelo princípio. A eficácia negativa, por sua vez, associa ao princípio a consequiência pela qual são considerados inválidos todos os atos ou normas que lhe contravenham.

4) As eficácias interpretativa e negativa, embora fundamentais na construção da normatividade dos princípios, apenas atendem às situações em que há uma violação comissiva do princípio. Elas não satisfazem quando o princípio pode ser violado também por omissão, como é o caso do princípio da dignidade da pessoa humana. Nesse caso, é preciso elaborar alguma forma de eficácia positiva, ou modalidade de conseqüência jurídica perfeitamente simétrica, para extrair determinadas prestações positivas do princípio, sem as quais ele se considera violado.

5) O primeiro passo para extrair prestações positivas do princípio da dignidade da pessoa humana é precisar quais são os efeitos que tal princípio pretende produzir.

6) Quanto aos efeitos, o princípio da dignidade da pessoa humana abriga dois aspectos: um que corresponde a um núcleo mínimo, consenso público transformado em norma jurídica, decisão fundamental do constituinte originário; e outro que será desenvolvido na esfera política, mediante deliberações específicas, de acordo com as opções da população. São os efeitos que se encontram naquele primeiro espaço 
- o espaço jurídico - que interessam para o fim de estabelecer o que pode ser exigido com fundamento nesse princípio.

7) De acordo com um consenso lógico contemporâneo e com a própria sistemática da Constituição brasileira de 1988 , uma proposta de concretização desses efeitos exigíveis diante do Poder Judiciário, sem os quais o princípio da dignidade da pessoa humana se considera violado, deve incluir: (i) ensino fundamental gratuito; (ii) prestações de saúde preventiva e (iii) assistência aos desamparados. 